\title{
Cruise Ship Tourism on the Danube in Vojvodina Province as a Segment of Global Tourism
}

\author{
Aleksandra S. Dragin', Vojislav \\ Dragin², Jovan Plavša', Andjelija \\ Ivkov', Branislav S. Djurdjev'
}

\begin{abstract}
Tourist packages based on cruises on the Danube river through Central and Eastern Europe represent a joint tourist offer of the countries in the area. The aim of the paper is to explore the potential benefits for the receptive countries and regions, particularly Vojvodina (Province of Serbia) by launching this tourist product to the world market. The results of the analysis have shown that the Danube cruises have positive impact on Vojvodina Province, primarily the riparian area of the Danube. Although the benefits exclude food and accommodation expenditure, they are noticeable within the following segments: tourism promotion (broadening the scopes of Vojvodina Province as a receptive area for the foreign market through its cultural heritage and natural values); increase in foreign tourist turnover, other expenditures; new job opportunities (adequate infrastructure and superstructure - rendering services to ships, crew and passengers) - harbors, carriers, souvenir shops, etc.

The results of the research may initiate further studies on the cause and effect connections between this type of traveling and resources of receptive countries, upon which the travels are based, both aiming at adequate design and launching of the tourist offer, i.e. the optimal development of receptive countries through sustainable tourism.
\end{abstract}

Key words: Global tourism, Cruise, the Danube, Southeastern Europe, Vojvodina Province, Serbia, transition, positive impact on local economies.

\footnotetext{
Department of Geography, Tourism and Hotel Management, Faculty of Sciences, University of Novi Sad, Trg Dositeja Obradovića 3, 21000 Novi Sad, Serbia

2 JKP "Gradsko zelenilo", Novi Sad, Nikole Tesle 1a, 21000, Serbia
}

\section{Introduction}

Modern cruising, which originated around 1970 , is the fastest growing, most dynamic segment of the travel and tourism industry (Cruise Lines International Association (CLIA) 1992). Also, cruise business is one of the major growth areas of international tourism (CLIA 1995; Hobson, 1993; Peisley, 1995; Kester, 2003). The World Tourism Organization conducted the Tourism Vision Study in 1998 and predicted that five most popular tourism products emerge over the next two decades would be cultural tourism, adventure tourism, ecotourism, cruise tourism and thematic tourism.

The annual turnover of cruises was 14.3 million tourists in 2004, with the estimated increase to 15 million tourists in 2006 and 20 million in 2012 (Cruise Information Service, 2005). Cruise offerings today include short trips to nearby places, as well as longer journeys within large regional areas (Marty, 2004).

Besides the main motif of the cruise, nautical product comprises utilization of nautical infrastructure and its complementary products and services in tourism (marines, harbours, docks, accommodation and food, entertainment, culture, etc.) The phenomenon breathing, life into the cruise market is segmentation - dividing each cruise into many shorter voyages, which can be booked separately, with an array of optional land tours (McDowell, 1995).

World nautical market on still waters (rivers, canals and lakes) is mainly focused to three centres: Europe, Africa (the Nile), and Far East (the Yangtze). River cruises turnover was about 1.3 million tourists in 2003 , which was about $11 \%$ increase of the turnover compared to 2002 in the world. River cruises are based on several day voyages (7-21 days) through several countries (Danube Tourist Commission, February 2004, taken from Horwath Consulting $\mathrm{Za}$ greb and Faculty of Economics Belgrade (HCEF) 2005).

According to estimations, there are over 15,000 navigable kilometres in Europe, including the canal network. The most pop- ular rivers are: the Danube, the Rhine, the Neva, the Volga, the Elba, the Seine, the Rhone and the Po (HCEF, 2005).

Such tendencies at the tourist market occur due to the increase in living standards of the population in certain countries, higher competition of vessels offering lower prices of services (especially ships from Russia, Ukraine, Bulgaria, etc.), as well as segmentation of tourist demand and offer intended for revealing new tourist attractions. Tourist recreation has become achievable to the wider population and found its position in their philosophy of life. Within the global tourism development, the Danube occupies a leading position within both demand and offer, which is confirmed by the data (HCEF, 2005) for 2003 when about 392,766 tourists participated in the Danube river cruises (then follow the Nile with 266,978 and Yangtze with 151,459 tourists).

Therefore, the designers of the tourist products, based on the Danube river, tend to provide dynamic and stable balance of offer and demand, by fine tuning of marketing mix basic instruments (product, price, sales forms and promotion) to market demands; what is more, to direct the demand towards the offer through tourist communication by means of homological and analogical codes.

The Danube river cruises highlight the attractiveness of the river basin and numerous complementary tourist values of natural and anthropogenic content. The tourist offer design emerges as one of the most important activities of tourist product designers (leading American and European tour operators). The proper design of a tourist package requires a detailed study of the market (target groups research, "innovative" destinations, redesigning of the "old" tourist offer, etc.)

Tour operators charter the vessels; whereas tourist agencies render services to the cruise tourists on land and charter the vessels' capacities to be included in their programmes.

Tour packages offers of the Danube river cruises comprise various activities, among which stand the airline transport, railroad 




Map 1 Position of Vojvodina Province in Europe

routes between the cities in the itinerary, accommodation facilities on vessels and in hotels, exclusive trips (sightseeing of the towns, vine tours, visits to castles and art colonies, etc.), cultural, educational and artistic programmes, dinner with the ship captain, additional services (e.g. information desk on the ship, sports and recreational activities, optional visits), etc.

The basic accommodation facilities are the vessels themselves and the hotels in towns. For example, the ships "M/S River Adagio" and "M/S River Aria" belong to the Danube river cruises private fleet of Grand Circle Travel (tour operator from the USA, Boston with its seat for Southeastern Europe in Basel, Switzerland), whose main emissive area is the American market. The ships fall within the deluxe category, with the length of $125 \mathrm{~m}$ and width of $11.5 \mathrm{~m}$ and four decks each. The accommodation capacity is 164 beds $(82$ cabins - all outside). The ship's crew is international, 38 persons of different professions: nautics, medical staff, caterers, etc.
The ships "M/S River Aria" and "M/S River Adagio" were launched in 2001 and 2003 respectively. Other ships from the private fleet of the tour operator ("M/S River Concerto", "M/S River Harmony", "M/S River Rhapsody", "M/S River Melody", "M/S River Symphony") are also registered in Switzerland. Conceptually, they appear identical, but with smaller accommodation capacity (140 passengers) and shorter in length 110m (Grand Circle Travel, 2004).

The ship structure comprises the following structural elements: reception area, cabins as basic accommodation units, restaurants and bars, library, shopping mall, sports, recreation and relaxation complex (gym, swimming pool, Jacuzzi), kitchen, storage facilities, staff premises, elevator, staircase, terraces, etc.

The origin countries of the tourist packages to be analyzed in the paper (with Vojvodina Province within the itineraries) are Austria, Hungary, Serbia, Romania, and Bulgaria. Most of the itineraries also include the border regions of Germany,
Slovakia, Moldavia, and Ukraine. It is also important to establish the cause-effect relationship of the cruises on the Danube region.

\section{Study Background}

Tourist cruises were stopped on the Lower Danube during the war activities on the territory of the former Yugoslavia (Croatia, Bosnia and Herzegovina, and Serbia). In 1999, the river traffic on the Danube in the area of Novi Sad (the capital of the Autonomous Province of Vojvodina) was made difficult and even blocked for the vessels due to the destruction of all three bridges in NATO bombing. Positive political changes in Serbia and the full clearance of Novi Sad section of the Danube finally brought to its reopening for cruises, making the river navigable again between Novi Sad and Constanta (1,255 river kilometres) in 2002. The Danube River cruises through Central and South-eastern Europe were in expansion concentrating on their main emissive areas, the USA and Germany. Since 2002, the tour operators of the Danube River cruises have been renting dozens of vessels of Swiss, German, Austrian, Hungarian, Bulgarian, and Ukrainian shipping companies (Dragin et al., 2004).

The aim of the paper is to explore the benefits of the launching of tourist product to the world market for receptive countries and regions, in this case for Vojvodina Province. Regional benefits can be quite substantial, especially where additional expenditure from cruises leads to a positive impact, for example, on employment in the region (Dwyer and Forsyth, 1998).

\section{Sampling}

Our focus of interest was the area of Vojvodina Province, i.e. western part of Serbia (Map 1).

The area of research comprises the section of the Danube, between Bezdan (Serbia - Vojvodina Province, on the border with Croatia) and Banatska Palanka (on the border with Romania). The length of the section is 350 river kilometres. The choice of the research area was influenced by the contemporary tendencies of river cruises, which show that this section of the Danube has been a frequent international tourist waterway in the last five years. Those cruises have positioned Vojvodina Province among the significant tourist destinations.

With the aim of presenting the turnover of the Danube river cruises through Vojvodina (i.e. Central and South-eastern Europe), statistical data, obtained from the Border Police Station in Novi Sad (Port of Novi Sad) and JKP "Gradsko zelenilo" (Port "Novi Sad II") for the period 2002-2005, have been processed. Their primary role includes harbouring the ships 
and providing services for ships, crew and tourists.

The most widely represented cruisers are: "River Aria" (Crand Circle Travel Cruise Line, Worldwide RC Ruises), "Heinrich Heine" (Viking River Cruise), "Ms Johann Strauß" (Austrian River Cruises), "Maxima" (Phoenix Reisen Gmbh Bonn), "Ms Victor Hugo" (L'Europe en Croisières), "River Adagio" (Crand Circle Travel Cruise Line, Worldwide RC Ruises), "Beethoven" (L'Europe en Croisières), "River Navigator" (Deluxe World Travel Vantage), "Odyssey" (Deluxe World Travel Vantage), "Erasmus" (B.V. Scheepvaart MIJ.), "Ms Artistry" (Avalon Waterways), “Amadeus" (Lüftner Reisin Austria), etc.

The ships harboured at the Port of Novi Sad, the capital of Vojvodina Province were included in various tourist packages of numerous tour operators. Tourist package "Eastern Europe to the Black Sea" includes the middle and the upper Danube basin area - Budapest, Vukovar, Novi Sad, Belgrade, Constanta, Bucharest (Grand Circle Travel 2004). Similar itinerary is observed with packages "Cruising the Danube to the Black Sea" and "Eastern Europe \& the Black Sea" (Vantage, 2005), i.e. "Eastern European Odyssey (Viking River Cruise, 2006). Most of the countries included in itineraries are former socialist countries, undergoing the process of transition in the last fifteen years (Dragin, 2005), making enormous efforts in promoting and developing tourism with the aim of establishing it as a future leader of economic prosperity.

\section{Analysis and methods}

The research was conducted on the crews of tourist vessels, tour operators and tourist agents of receptive tourist agencies; the applied method was the interview.

Statistical and comparative methods are the most frequently applied tools in the analysis of annual and monthly tourist turnover (the number of vessels and tourists) for the period 2002-2005, on the basis of which quantitative features of tourist turnover are identified and demand trends are established; concerning the facts about this form of tourism, whether it undergoes expansion, stagnates or lacks in high attractiveness of the offer.

\section{Results}

With the aim of more thorough observations of quantitative and qualitative features of the Danube River cruises turnover and its influence on tourism in Vojvodina Province, the specific features of the offer are presented and analyzed in the paper.

\section{Tourist product and price of tourist} arrangements - specific features of the offer

The prices of the Danube river cruise package (Budapest - Constanta) range between
1,695 - 5,00o USD depending on the period, ship category and deck, and the airline ticket (Grand Circle Travel, 2005; Vantage, 2005).

The prices for 2006 were established according to the 13 days package "Eastern Europe to the Black Sea" ranging from 1,695 to 3,695 USD. Tourist arrangements comprised the following elements/services: return plane ticket on international flights from the USA (Boston, Miami, New York) to Hungary (Budapest) arrival, and departure from Romania (Bucharest) to the USA (Boston, Miami, New York); two transfers airport- hotel; 7 nights on the ship Grand Circle Travel deluxe; 3 nights in Budapest in a five star hotel and 1 night in Bucharest in a five star hotel; 27 meals (11 breakfasts, 7 lunches, and 9 dinners); 6 exclusive tours guided sightseeing of the towns (Budapest, Osijek, Novi Sad, Belgrade, Constanta, Bucharest); railway transport (ConstantaBucharest); exclusive events - lunch from domestic cuisine in Croatia, lessons on recent past of the former Yugoslavia; oral presentation of the ports in the itinerary; land transports - coaches; information maps, postcards and tickets for individual sightseeing; $5 \%$ discount for the next voyage with Grand Circle Travel (minimum of 84 USD per person); one luggage bag per person (Grand Circle Travel, 2005).

Tour operator Vantage offers a similar programme of the same length, under the name "Eastern Europe \& the Black Sea". The prices in 2006 ranged from 2,799 to 4,999 USD. The following services were included: return overseas plane ticket (international flights by schedule from Boston, New York and Philadelphia); 10 nights on the deluxe ship; 1 night in Bucharest in a five star hotel; 31 meals (11 breakfasts, 10 lunches, and 1o dinners); 6 exclusive guided tours - Bucharest, Constanta and Ma- maia, Russe, Veliko Trnovo and Arbanasi, Belgrade, Osijek, Budapest, village Holoko); transfers to and from airport and luggage; exclusive programme "Cultural ties" - lunch from domestic cuisine in Osijek and Holoko, lessons on history and culture of the area; Hungarian, Romanian and Croatian folklore nights on the ship, Bulgarian children's dance, lunch with the students in Arbanasi, icon paintings demonstration in Romania, half a day excursion to a Hungarian authentic farm (riding skills presentation and carriage rides on authentic farm), half a day excursion to Slovak art centre in Kovacica including visits to art galleries and houses of painters (Vojvodina Province); 5\% discount for the next voyage with this company (Vantage, 2005).

In order to analyse the specific features of the tourist packages and the values of the tourist offer of the Danube cruises through Central and South-eastern Europe, i.e. Vojvodina, various cruise prices (only the lowest prices included) of tour operator Vantage are listed in the paper.

The point that tour operators Grand Circle Travel and Vantage are directed towards the USA as their emissive tourist market is supported by the fact that tourist packages include airline transport from the USA only (Boston, New York, Philadelphia, Chicago, Washington, Atlanta, Baltimore, Miami, Orlando, Los Angles, San Francisco, Dallas, Denver, Detroit, Huston), as well as the prices expressed in US dollars only (Grand Circle Travel, 2005; Vantage, 2005).

The 9 days tourist package "Du Danube vers la Tisza, la Hongrie profonde” of the tour operator Croisi Europe offers the Danube and Tisa cruise with the following itinerary: Budapest - Mohacs - Bezdan - Novi Sad - Titel - Kanjiža (Vojvodina

Table 1 European River and Canal Cruise Travels

\begin{tabular}{|l|l|r|r|}
\hline $\begin{array}{l}\text { Tourist package } \\
\text { (countries included in itinerary) }\end{array}$ & River & $\begin{array}{l}\text { Length } \\
\text { (days) }\end{array}$ & $\begin{array}{l}\text { Price } \\
\text { (US\$) }\end{array}$ \\
\hline $\begin{array}{l}\text { "GRAND EUROPEAN RIVER CRUISE" (Holland, Germany, } \\
\text { Austria, Hungary, Croatia, Serbia, Bulgaria, Romania)* }\end{array}$ & $\begin{array}{l}\text { Rhine, Main, } \\
\text { Danube }\end{array}$ & 27 & 4.999 \\
\hline $\begin{array}{l}\text { "ENCHANTMENT ALONG THE RHINE \& MOSELLE" } \\
\text { (Germany, France, Switzerland) }\end{array}$ & $\begin{array}{l}\text { Rhine, Main, } \\
\text { Moselle }\end{array}$ & 16 & 3.699 \\
\hline $\begin{array}{l}\text { "Holland to Hungary River Cruise" } \\
\text { (Holland, Germany, Austria, Hungary) }\end{array}$ & $\begin{array}{l}\text { Rhine, Main, } \\
\text { Danube }\end{array}$ & 16 & 2.699 \\
\hline $\begin{array}{l}\text { "CRUISING THE DANUBE TO THE BLACK SEA" (Austria, } \\
\text { Slovakia, Hungary, Serbia, Bulgaria, Romania)* }\end{array}$ & Danube & 17 & 3.199 \\
\hline $\begin{array}{l}\text { "EASTERN EUROPE \& THE BLACK SEA" } \\
\text { (Hungary, Croatia, Serbia, Bulgaria, Romania)* }\end{array}$ & Danube & 13 & 2.799 \\
\hline $\begin{array}{l}\text { "IMPERIAL RUSSIAN WATERWAYS \& ST. PETERSBURG" } \\
\text { (Russia) }\end{array}$ & Volga, Svir & 16 & 2.399 \\
\hline $\begin{array}{l}\text { "HOLLAND \& BELGIUM IN BLOOM" } \\
\text { (Holland, Belgium) }\end{array}$ & $\begin{array}{l}\text { Rhine and } \\
\text { canals }\end{array}$ & 12 & 1.999 \\
\hline
\end{tabular}

*Tourist packages with Vojvodina Province included in itineraries

Source: Vantage, 2005 
Table 2 Annual turnover of tourist ships and tourist in Novi Sad (The Danube River cruises through Vojvodina Province)

\begin{tabular}{|l|c|c|c|c|}
\hline Annual turnover & $\mathbf{2 0 0 2}$ & $\mathbf{2 0 0 3}$ & $\mathbf{2 0 0 4}$ & $\mathbf{2 0 0 5}$ \\
\hline The number of harboured ships & 29 & 64 & 121 & 285 \\
\hline Total number of passengers & 1,563 & 4,687 & 15,504 & 34,077 \\
\hline
\end{tabular}

Source: Documentation of Public Utility Company "City Parks" and Port of Novi Sad (2002-2005)



Graph 1 Annual turnover of tourist ships and tourists and the turnover increase in \% compared to the previous season (year) in Novi Sad (the Danube river cruises through Vojvodina Province)

Province) - Szeged - Csanytelek - Szolnok - Tiszafüred - Tokaj. The price in May and June is $863 €$, including the following services: full board in air-conditioned cabin with double bed, welcome cocktail, gala dinner, staff services, port taxes and an excursion (Opusztaszer). The price does not include the insurance policy, optional excursions, airport taxes, etc. (Croisi Europe, 2006).

The second tourist package (11 days) with the same tour operator is "Du Danube Bleu vers la Mer Noire" with the following itinerary Strasbourg - Linz - Melk - Vienna - Bratislava - Budapest - Mohacs - Bezdan - Novi Sad (Vojvodina Province) - Belgrade - Donji Milanovac - Russe Giurgiu - Oltenita - Tulcea. The price for the cruises in June, July and August is $1,480 €$. The price includes the following services: full board in air-conditioned cabin with double bed, welcome cocktail, gala dinner, staff services, transfers from and to the airport, the plane ticket Constanta - Strasbourg, port taxes, folklore dances (Rousse, Tulcea), road transport Passau -Strasbourg and transfer to the airport on departure. The price does not cover the insurance policy, optional excursions, airport taxes, etc. (Croisi Europe, 2006).

Qualitative and quantitative indicator of the recognisable features in the Danube rive cruises through Central an Southeastern Europe ( and Vojvodina Province) and the significant role of promotion and sale activities of tour operators and tourist agencies is the tourist turnover - its scope and dynamics.

\section{Tourist turnover}

It was the continental climate of Central and South-eastern Europe which influMarch, seven in April, eight in May and cruises through Vojvodina Province) cruises through Vojvodina Province)
June, seven in July and August, six in September and October, and two in November (Grand Circle Travel 2005). The peak season (eighth eh highest demand) is in the period from April to August, which is observable in the number of offered cruises. The prices in that period are higher due to favourable climate conditions.

The 13 days package "Eastern Europe and the Black Sea" of Vantage company is offered two or three times a month on average (Vantage 2005). This programme is far less frequently offered to the foreign marker in comparison to the former package of Grand Circle Travel company (which is also evident in the total number of offered cruises during the season).

The company Viking River Cruise of fers a tourist package with the 15 to 18 days itinerary Budapest - Black Sea - Vienna (Budapest - Pecuj - Belgrade - Bucharest - Constanta - Russe -Vidin - Orsova - Novi Sad - Vukovar - Kalocsa - Vienna) with two cruises a month on average (Viking River Cruise 2006).

For the presentation of tourist turnover of the river cruises the statistical data of the Border Police Station in Novi Sad and Public Utility Company "City Parks" were processed for the period 2002-2005 (Table 2).

The actual turnover in the 4 year period (following the clearance of the Danube section after the bombing of the bridges in Novi Sad) highlights the permanent increase in the demand, which was met by the increase in the number of river cruises in the each following year (Graph 1).

The list of the vessels of the most frequent cruisers (companies) in this area:

Table 3 Monthly turnover of tourists (March - November) in Novi Sad (the Danube river

\begin{tabular}{|l|r|r|r|r|r|r|r|r|r|r|}
\hline $\begin{array}{l}\text { NNo of } \\
\text { tourists }\end{array}$ & MAR & APR & MAY & JUN & JUL & AUG & SEP & OCT & NOV & Annual \\
\hline 2002 & - & 43 & 229 & - & 27 & 500 & 483 & 281 & - & 1,563 \\
\hline 2003 & - & - & 399 & 969 & 1,520 & 730 & 367 & 702 & - & 4,687 \\
\hline 2004 & - & 768 & 1,039 & 3,285 & 4,816 & 3,286 & 1,320 & 990 & - & 15,504 \\
\hline 2005 & 477 & 1,938 & 4,371 & 6,508 & 6,112 & 4,781 & 5,180 & 4,424 & 286 & 34,077 \\
\hline
\end{tabular}

Source: Documentation of Public Utility Company "City Parks" and Port of Novi Sad (2002-2005)

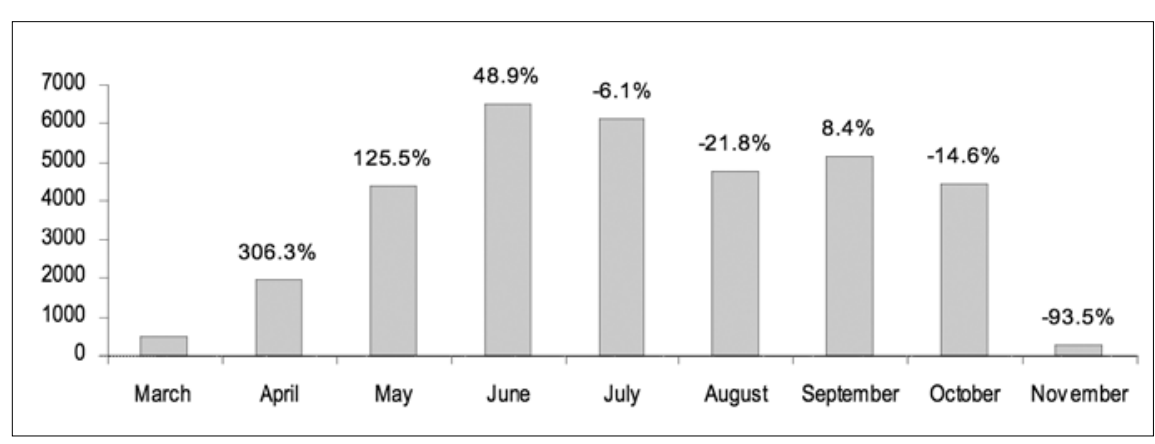

Graph 2 Monthly turnover of tourists (March - November) and its increase/decrease (in $\%$ ) in comparison to the previous month in Novi Sad for the year 2005 (the Danube river 
"River Aria" (Grand Circle Travel Cruise Line, Worldwide RC Cruises), "Heinrich Heine" (Viking River Cruise), "Ms Johann Strau $\beta$ " (Austrian River Cruises), "Maxima" (Phoenix Reisen Gmbh Bonn), "Ms Victor Hugo" (L’Europe en Croisières), "River Adagio" (Grand Circle Travel Cruise Line, Worldwide RC Cruises), "Beethoven" (L'Europe en Croisières), "River Navigator" (Deluxe World Travel Vantage), "Odyssey" (Deluxe World Travel Vantage), "Erasmus" (B.V. Scheepvaart MIJ.), "Ms Artistry" (Avalon Waterways), "Amadeus" (Lüftner Reisen Austria)

Tourist turnover dynamics specifies that the main tourist season occurs in the period April - October, i.e. that the Danube is an actual and significant tourist destination in the 7 month period which also positions Vojvodina Province, the Danube receptive area, within the list of significant tourist destinations (Table 3 and Graph 2).

Concerning the target groups as the market segment, most of them are found in Germany and the USA. In addition, it has been established that $78 \%$ participants in such voyages belong to the category $55+$. Therefore the services on board ships are tuned to meet the needs of the aforementioned age group (light meals, elevator, wheelchair access, excluded sport capacities on board ship, etc.) Aiming at younger age groups, tour operators prepare the introduction of additional facilities intended for the younger population in 2007 (volleyball court and open air discotheque on the top deck), and announce new concept of the programmes in their promotional activities (Documentation of Port "Novi Sad II" 2006).

\section{Cruise Ship Tourism Impact on Local Economy}

After the bridges on the Danube in Novi Sad were bombed in 1999, the clearance of the Danube basin in that area was commenced by the support of the European Union, the Danube Commission and Corridor VII-Management/TINA Vienna. Two new bridges were built and one pontoon bridge was constructed, with the opening schedule of three times a week to make passage for ships. Thus, the Danube was at least, even with some restrictions, made navigable again as far as to its delta in Romania. On the iniciative of the Danube Tourist Commission, passenger ships did not have to pay any toll.

By the year 2004, there was only one harbour in Novi Sad - the Port of Novi Sad (on the left bank of the Danube, downstream the pontoon bridge). Following the initiative of the Traffic Office in Novi Sad, the new harbour was opened for tourist vessels - Port of Novi Sad 2 (on the right bank of the Danube, upstream the pontoon bridge). This resulted in direct access of tourist vessels that were cruising down- stream from Budapest to Belgrade, and more convenient disembarking of tourists according to the itinerary, without any delays considering the opening schedule of the pontoon bridge.

In October 2005 the third bridge in Novi Sad was reconstructed - the Sloboda (Freedom) Bridge and the pontoon bridge was finally removed. That meant that navigation on the Danube had been fully restored.

The benefits of river cruises on the middle and lower Danube, concerning Vojvodina Province are numerous:

- Increase in the total tourist turnover in Vojvodina Province. The share of the participants in this form of tourist activities compared to the total foreign tourist turnover in Vojvodina in 2002 was additional $6.79 \%$, in $200319.21 \%$, in $200462.84 \%$, and in 2005 their share reached additional $117.51 \%$ (Statistical Office of the Republic of Serbia 2003, 2004, 2006). In comparison to the total foreign tourist turnover in Vojvodina they participated with additional 3.15\% in 2002 , in 2003 with $9.50 \%$, in 2004 with $27.34 \%$, and in 2005 with $48.68 \%$ (Statistical Office of the Republic of Serbia, 2003, 2004, 2006).

- Discovery of Vojvodina as a tourist destination for potential emissive areas at the international tourist market - creation of the image of Vojvodina as an attractive receptive tourist area through the promotion and sale of tourist packages:

The area abundant in significant natural tourist resources (protected natural values in the Danube riparian area, national parks, etc.), attractive hydrography (canals and smaller rivers); Geo-heritage, etc.);

Multiethnic and multicultural features (over 24 nations);

Significant cultural heritage (archaeological sites, medieval fortifications, authentic urban and rural units, etc.).

- The development of tourist infrastructure and superstructure (the reconstruction of the quay in Novi Sad is in process, including the parking facilities for tourist buses, and more convenient access for tourists).

- Opening of new job posts - employment possibilities (new harbour, souvenirs production, production of food and drinks of geographical origin, etc.). Due to permanent increase in tourist ships frequency on the Danube, and subsequently the increase in the number of harboured ships in Novi Sad, the function of the Port of Novi Sad 2 did not stop with the removal of the pontoon bridge. The Port was relocated downstream, on the left bank of the Danube, near the centre of Novi Sad in August 2006. Another example of the direct influence of Cruise Ship Tourism on new job opportunities is the opening of the souvenir market near the port for tourist ships in Novi Sad in 2006.

- Business of the Port of Novi Sad and Port of Novi Sad 2.

- Increase of the total expenditure through foreign tourist payments of various services:

Ship services - harbouring and tax; Issuing passenger permits for stays in border region;

Shipping transport agencies;

Fresh drinking water services from the local water supplies in Novi Sad (Public Utility Company "Water Works and Sewerage") and sanitation services for ships (Public Utility Company "City Sanitation"). For example daily fresh water demands of a river cruise are approximately 70-100 $\mathrm{m}^{3}$ and daily waste disposal reaches several $\mathrm{m}^{3}$.

Tourist sojourn tax (the city of Novi Sad);

Foreign currency exchange in exchange offices and banks;

Coach transport services (mainly offered by transport companies: "Vojvodina", "Putnik" and "Lasta");

Sightseeing tours of the city, the Petrovaradin Fortress, Sremski Karlovci, monasteries of Fruška gora, etc. (receptive travel agencies, i.e. "Putnik") and guiding services;

Evening concerts of folk dance associations during the cruise stay in the harbour;

Entrance tickets for various institutions and tourist localities during the sightseeing tour of Novi Sad and its surroundings (the Museum of Vojvodina, the Museum of the town of Novi Sad, etc.) - the growth of the income of tourist localities;

Individual expenditures of tourists during the sightseeing tours of Novi Sad and its surroundings (purchase of souvenirs, postcards, fruit, drinks and food in restaurants and cafes, etc.)

\section{Discussion}

The results of the analysis show that cruising voyages on the Danube influence many aspects of the development of the Vojvodina region: the growth of tourism turnover (increased tourism expenditures, increased income of tourism localities, etc.); broadened positive marketing of Vojvodina at the foreign tourist markets; new investments and new employment opportunities (adequate infrastructure and superstructure - various services for ships, crew and passengers) - ports, souvenir shops, etc. 
Furthermore, certain resources in Vojvodina Province are directly related with the successful realisation of tourist packages concerning various services in case of emergency, medical services, petrol stations for coaches, foreign currency exchange, etc.

In order to improve the tourist offer and increase the stays of cruise vessels in Vojvodina Province, the main concern should be to build the accompanying elements in the vicinity of the port, such as coach parking (the construction in progress), exchange offices, petrol stations for ships, emergency units for minor repairs on vessels, etc.

The problem concerning the dislocation of distributive points of the Tourist Organization of Serbia, Tourist Organization of Vojvodina and Tourist Information Centre of Novi Sad, which are remote from the port for cruise ships and tourist localities, needs to be solved by introducing improved tourist sign posts and tourist information points.

It is necessary to highlight that such form of tourism stands for the only mass form of international nautical tourism in the area of Vojvodina Province and the whole country as well. According to the strict worldly criterion, the Danube section in Vojvodina Province stands for a high quality base for nautical tourism. It is also important to mention its attractive and miscellaneous hydrology, with several large tributaries, the connection with the canal network hydro-system "Danube-Tisa-Danube" and hundreds of backwaters, marshes and reeds, exclusive natural values (national park "Fruška gora", special nature reserves: "Gornje podunavlje", "Karađorđevo", "Koviljsko-Petrovaradinski rit" and "Deliblatska peščara"), and anthropogenic values (settlements, fortresses, archaeological sites, etc.). However, the aforementioned section of the Danube renders poor infrastructure and superstructure, there is also underutilization of the section by the domestic nautical teams, but there utilization initiative through cruise ship tourism by foreign tourists.

\section{Acknowledgements}

The paper is part of the Project (Contract of the project: EVB: 146017 "Demographic transition in Serbia", financed by the Ministry of Science) and also a part of the doctoral studies research of MSc Aleksandra Dragin.

The authors would like to thank Jovan Stanisavljević, Branimir Lazić and Zlatko Grabež (Public Utility Company "City Parks", Novi Sad) for his assistance in obtaining and interpreting data from archives of Port "Novi Sad II" and Port "Novi Sad".

\section{References}

Cruise Lines International Association (CLIA). 1992. The Cruise Industry: An Overview. New York: Cruise Line International Association.

Cruise Lines International Association (CLIA). 1995. The Cruise Industry: An Overview. Marketing Edition. New York: Cruise Line International Association.

Croisi Europe. 2006. L'Europe en Croisières, Strasbourg.

Cruise Information Service. 2005. Annual Cruise Review 2004 (UK and Europe) December 2006. www.discover-cruise. co.uk

Dragin, V. 2005. Tour Operator's Role in Advertising and Sale of Circular Danube tours. Turizam 9, 106-107.

Dragin, V., Ivkov, A., Maletin (Dragin), A. 2004. Cruising Voyages Along the Danube as a Form of Contemporary Tendencies of Global Touristic Movements. Turizam 8, 19-21.
Dwyer, L. and Forsyth P. 1998. Economic Signification of Cruise Tourism. Annals of Tourism Research 25, 2, 393-415.

Grand Circle Travel. 2004. The Great Rivers of Europe. Kansas City.

Grand Circle Travel. 2005. Small Ship Travel 2006. Grand Circle Travel, Boston.

Hobson, J.S.P. 1993. Analysis of the US Cruise Line Industry. Tourism Management 13, 453-462.

Horwath Consulting Zagreb i Ekonomski fakultet Beograd (HCEF). 2005. Strategija turizma Republike Srbije (Prvi fazni izveštaj). Ministarstvo trgovine, turizma i usluga Republike Srbije, Beograd.

Kester, J.G.C. 2003. Cruise tourism. Tourism Economics 9, 3, 337-350.

Marti, B. E. 2004. Trends in world and extended-length cruising (1985-2002) Marine Policy 28, 199-211.

McDowell, E. 1995. After the storms, ships sail on. The New York Times, October 8, 11-31.

Peisley, T. 1995. The Cruise Ship Industry to the 21st Century. Economist Intelligence Unit. Travel and Tourism Analyst 2, 4-25.

Statistical Office of the Republic of Serbia. 2003 Municipalities of Serbia in 2002. Belgrade: Republic Printing Office.

Statistical Office of the Republic of Serbia 2004. Municipalities of Serbia in 2003. Belgrade: Republic Printing Office.

Statistical Office of the Republic of Serbia. 2006. Statistical Yearbook of Serbia Belgrade: Republic Printing Office.

Deluxe World Travel Vantage. 2006. European River Cruises Preview, Vantage, Boston.

Viking River Cruise. 2006. European \& Russian 2007. River Cruise Journeys. California: Woodland Hills. 